\title{
INTERACTIONS BETWEEN THE EPISTEMOLOGICAL PERSPECTIVE OF NURSING EDUCATORS AND PARTICIPANTS IN EDUCATIONAL PROGRAMS: LIMITS AND OPPORTUNITIES TOWARD THE DEVELOPMENT OF QUALIFICATION PROCESSES FOR THE PROMOTION OF SELF-CARE IN HEALTH
}

\author{
Sheila Sanchez Gomez¹, José Luis Medina Moya²
}

\footnotetext{
${ }^{1}$ Ph.D. in Nursing. Professor at the Vitoria-Gasteiz Nursing School. Family and Community nurse at the Vasco Healthcare Service. Vitoria-Gasteiz, Spain. E-mail: sheila.sanchezgomez@osakidetza.net

${ }^{2}$ Ph.D. in Philosophy and Education Science. Professor at the Pedagogy Faculty of the Universidad de Barcelona. Barcelona, Spain. E-mail: jlmedina@ub.edu
}

\begin{abstract}
Research-action aimed at exploring and transforming teaching-learning processes performed by nurses focused on the empowerment of mature adults toward self-care. An educational program was launched in two different locations, where educational sessions and post-educational reflexive meetings with nursing professionals were carried out. The selection and sampling of participants - nurses and mature adults - was intentionally pointed out. Employed methodologies were as follows: participatory observation (video recording of sessions); in-depth interviews; and reflexive sessions about educational practices. Data analysis was performed by means of the constant comparative method. Results pointed to the current coexistence of different educational interests concerning the healthcare education, the need for building dialogues between the participants' and nurses' frameworks, and the need for advancing toward more autonomous epistemological reference points that are able to forge healthcare-based dialogical learning pillars.

DESCRIPTORS: Community health nursing. Health education. Health promotion. Consumer participation. Community-based participatory research.
\end{abstract}

\section{LA INTERACCIÓN ENTRE LA PERSPECTIVA EPISTEMOLÓGICA DE LAS ENFERMERAS EDUCADORAS Y LOS PARTICIPANTES (EN PROGRAMAS EDUCATIVOS): LÍMITES Y OPORTUNIDADES EN EL DESARROLLO DEL EMPODERAMIENTO PARA EL FOMENTO DEL AUTOCUIDADO EN SALUD}

\footnotetext{
RESUMEN: Investigación-Acción que pretende explorar y trasformar los procesos de enseñanza-aprendizaje, desarrollados por enfermeras, orientados hacia la capacitación para el autocuidado y el empoderamiento del colectivo "adulto maduro". Se ha puesto en marcha un programa educativo en dos localidades donde se intercalan sesiones educativas con encuentros reflexivos post acción educativa con las enfermeras formadoras. La selección y muestreo de los participantes, enfermeras y colectivo "adulto maduro", es intencional. Los métodos utilizados son: observación participante (grabaciones en video de las sesiones), entrevistas en profundidad y sesiones reflexivas sobre la práctica educativa. El análisis de datos se realiza a través del método de comparaciones constantes. Los resultados muestran la convivencia de distintos intereses educativos presentes en la actualidad en torno a la educación para la salud, la necesidad de poner en diálogo los marcos de referencia de participantes y enfermeras y de avanzar hacia posiciones epistemológicas más autonomizantes que forjen los pilares del aprendizaje dialógico en salud.

DESCRIPTORES: Enfermería en salud comunitaria. Educación en salud. Promoción de la salud. Participación comunitaria. Investigación participativa basada en la comunidad.
} 


\title{
A INTERAÇÃO ENTRE A PERSPECTIVA EPISTEMOLÓGICA DAS ENFERMEIRAS EDUCADORAS E PARTICIPANTES EM PROGRAMAS DE EDUCATIVOS: LIMITES E OPORTUNIDADES PARA O DESENVOLVIMENTO DE CAPACITAÇÃO PARA A PROMOÇÃO DO AUTOCUIDADO EM SAÚDE
}

\begin{abstract}
RESUMO: Investigação-ação que pretende explorar os processos de ensino-aprendizagem, desenvolvidos por enfermeiras, para capacitação para o autocuidado e o empoderamento do coletivo de idosos. Foi desenvolvido um programa educativo em duas localidades, no qual foram intercaladas sessões educativas com encontros reflexivos, após a ação educativa pelas enfermeiras educadoras. A seleção e a amostra dos participantes, enfermeiras e idosos foi intencional. Os métodos de coleta utilizados foram: observação participante, com a gravação em vídeo das sessões, entrevistas em profundidade e sessões reflexivas sobre a prática educativa. A análise dos dados foi realizada por meio do método de comparações constantes. Os resultados mostram a convivência de diferentes interesses educativos presentes na atualidade na educação para a saúde, a necessidade de colocar o diálogo como marco de referencia para os participantes e as enfermeiras e avançar para posições epistemológicas que favoreçam maior autonomia, a fim de forjar os pilares de uma aprendizagem dialógica em saúde.

DESCRITORES: Enfermagem em saúde comunitária. Educação em saúde. Promoção da saúde. Participação comunitária. Pesquisa participativa baseada na comunidade.
\end{abstract}

\section{INTRODUCTION}

The health promotion concept has broadened and become more complex throughout the years toward the construction of more systemic, community-based, participative perspectives. Health education emerges as one of the major strategies of this concept, aimed at promoting the health and empowerment of individuals and collective groups. However, we observe the coexistence of several different perspectives nowadays - or the "constitutive interests of knowledge", according to the conception created by Habermas ${ }^{1}$ regarding the healthcare educational practice.

Such interest guides and shapes the constitution of knowledge, in contrast with the diversity of the human activities, encompassing the different backgrounds that conform reality, and how one can act upon it. ${ }^{2}$ Habermas proposed that human knowledge is composed of three constitutive interests: technical interest, practical interest, and critical interest.

The basic foundation of the technical interest is the control, the objectivity and the management of the environment. As such, health education acquires an informative, unidirectional and medical-preventive perspective. In this sense, a hierarchic, vertical and unidirectional education is built, where the professional is the one who holds both the knowledge and the power, and the common person represents a passive depository of such knowledge.

The practical interest is basically oriented toward the comprehension of the environment and the agreed interpretation of reality. Under such perspective, health education is understood as a complex, socially built activity, in which educational processes spread their roots to the personal world of individuals and their meanings, their intentionality, their personal and collective construction of such process. In other words, the actions through which the learning process takes place are called "communicative actions". These actions influence the person's desires, interests, motivations, expectations and interpretations. ${ }^{3}$

The basic guideline of the critical interest is the empowerment, qualification and liberation of individuals and groups, so that they are able to take their lives in their hands in an autonomous, responsible way. This status grants them access to a type of self-reflexive comprehension that allows them to pinpoint objective social conditions that may hinder the fulfilment of rational goals and freedom. ${ }^{4}$ In the perspective of this latter interest, health education stands out as a participatory and democratic practice, as it highlights the dialogue, involvement and critical participation of individuals as key elements toward the emancipation of subjects and transformation of realities.

Care practice and health education have been seen from a fragmented and reductionist standpoint for a long time. Such perspective does not reflect the multidimensionality, subjectivity and social-historical reality in which the care practice has been constructed. In search for its professional legitimation, the nursing practice has incorporated the current positivist model, thus trapping people in its system and seizing self-care opportunities. In 
other words, this system has generated more and more people dependent on health professionals and sanitary services; on their turn, professionals and services need ever-increasing amounts of resources in order to respond to more and more critical demands. ${ }^{5}$

Nevertheless, several studies have found that the unidirectional transmission of information is insufficient either in self-care education or in professional qualification. ${ }^{6-7}$ As a matter of fact, self-care educational processes stand out as multidimensional, complex realities resulting from a number of correlations between subjects, institutions and (common and professional) knowledge. Hence, whenever a process of hyper-simplification of situations occurs, the uncertainties and ambiguities produced by educational processes are finally eliminated, thus generating a superficial comprehension of reality. ${ }^{8}$ The myth of the "infallible professional" is already outdated. Instead, we should address a dialogued understanding among different types of knowledge, in such a way that we are able to access the whole array of significances employed by individuals, assimilate other elements that could hinder self-care, advance toward a meaningful learning process, and enhance the decision power of individuals and groups regarding healthcare and community-based selfcare actions. However, how can we give self-care power back to populations and, at the same time, empower ourselves as a professional group?

In harmony with the above-mentioned issues, the objective of this study was to explore and transform the dialogical-reflexive learning processes carried out by nurses, aimed at qualifying mature adults to self-care, empowerment and promotion of a healthy life. This article intends to elaborate on the genesis of the research, that is, to present the rational framework and the epistemological presuppositions (perspective) that sustain and provide meaning to the health educational practices performed by nurses, as well as their interactions with mature adults and their own perspectives on self-care.

\section{METHODOLOGY}

A basic notion of health education as a complex practice leads us to understand that it is impossible to approach the concept outside of its natural scenario and far from the subjective experience of the protagonists of educational actions; in other words, from a holistic and qualitative standpoint. ${ }^{9}$
However, given our interest in expanding the comprehension of the complexity of such phenomenon, and in the transformation of the current reality of health education and the empowerment of subjects by means of their participation and critical epistemological reflection, this study acquires a social-critical character. ${ }^{10}$

Research-action studies stand out as the methodology-method that most represents the critical theory, as it seeks transformation through a reflexive and dialogical action. In this study, the contribution of this educational approach toward the implementation of the research-action cycles has been addressed. ${ }^{11}$

The target audience of the study was, first of all, a group of nurses with vast practical experience in primary health care and in the development of health education interventions with groups; secondly, a group of people defined as mature adults, just entering the aging phase. A theoreticalintentional sample of both groups was built up. The groups were comprised of 10 and 12 people, respectively, including women and men with ages ranging between 65 and 75 years.

The following methods were employed: participatory observation; in-depth interviews; and reflection sessions on educational practices. Aiming at providing rigor and veracity to the study, a combination of both methods and subjects was applied.

Participatory observation is defined as a learning process developed by the exposure and involvement of participants in daily practices or activities. ${ }^{12}$ In this case, a participant was expected to observe health educational activities. ${ }^{13}$

The tools used in the participatory observation were as follows: video recordings of the educational sessions, and a field diary. The video recordings facilitated a genuine immersion of the research into the study field.

The reflection sessions on the educational practice led us to a collective interpretation of the researched reality, based on reflections made by the actors themselves of this reality in relation to others and their contexts. Educational sessions were interspersed with meetings of reflection on action with nurses. The video recordings (meaningful scenes) were analyzed and the observed educational practice was reinterpreted, aiming at advancing in the abstraction of key dialogical and empowering learning elements. 
Based on our interest in deepening the meanings that participants gave to successful educational action events, and on our purpose of combining their interpretations, four in-depth interviews were carried out with two participants from each group.

Participants were required to sign a free and informed consent form to participate in the research, and to allow the use of the video recordings. The research proposal was approved by the reference CEIC of the Sanitary District under protocol RD 1720/2007, in compliance with confidentiality and anonymity criteria.

The field work was focused on the implementation of the research-action cycles and the co-construction of the learning process by means of the development of the educational program named "Self-care is on your hands", which concurrently occurred in two spots in the rural area of Álava, Spain.

Although an analytical comparison of contents was performed through the constant comparison method, ${ }^{14}$ the study intended to transversally carry out a more holistic approach aimed at revealing the social positions of those who produce different arguments and the decision makers in the process. In other words, the study intends to overcome the traditional content analysis and get closer to a more critical analysis of perceptions on the educational action. ${ }^{15}$

After the conclusion of the educational program (seven sessions with the population), the reflexive meetings with the nurses (six meetings), the interpretative exercise carried out with the population in the last session of the educational program, and the four in-depth interviews, we were able to come up with the interpretation clusters that would orient the first dialogical analysis of the transcriptions of the primary documents.

By means of the constant comparison method, the emerging category system was utterly refined, modified, cleansed and redefined. In this analytical phase, it is worth highlighting that the computerized program called Atlas-ti has been of great help. The final category system provides 46 categories and 10 meta-categories of deeper abstraction levels that integrate, describe and provide meaning to the categories contained in it. However, the general framework was finally explained by the qualitative vectors interconnecting the results, which produced specific correlations and meanings to the emerging thematic clusters and categories.
The first vector refers to previous frameworks (perspectives) displayed by both the participants and the nurses, combined with the discourse of the latter, which reveal the rationality that generates meaning to the care practices of the participants and also their way of perceiving the existing correlation between the practices and the professionals who carry them. On the other hand, they also referred to the educational practices of the nurses.

Grounded on a dialogical and emancipating learning process, the second vector addressed the educational keys that emerged as elements aimed at overriding the previously mentioned restrictive frameworks, which perpetuated power correlations and propagated a sense of dependence.

The third vector represented the reflexive learning process, where a reflexive exercise on the educational action arises as quite a useful key toward a practical-reflexive rationality in the pathway of coping with ambiguous, complex and unstable situations of the care practice and teaching.

This study employed the following codes: P: participants; N1, N2: participating nurses; R: researcher; Iz/Gp: places; S1-, S2-, S3-, ...: health educational sessions carried out with the group; Id-I1, Id-I2...: in-depth interviews carried out with participants; Rs-A-3, Rs-A-4,..: reflection sessions on the action carried out with the nurses.

\section{RESULTS AND DISCUSSION}

The educational practice is not an acritical, timeless practice. It is contextualized in a specific time and obeys to concrete social and cultural circumstances in which unique subjects interact. These subjects act based on their knowledge, experiences and values. Their actions are characterized by epistemological perspectives. Such perspectives are responsible for providing meaning to the different ways of understanding the health, care, education and existence of human beings. Such epistemological perspective of subjects, as we will see ahead, is not static or unique, as it evolves and moves within a technical-practicalemancipatory continuum, and takes place in occasions, contradictions and paradoxes stemming from the complexity of the educational action and the coexistence of interests.

The actions, statements and reflections of participants and nurses revealed the perspective, or epistemological approach, in relation to the educational practice and the health self-care, ex- 
plaining and providing a cross-sectional meaning to all educational actions.

\section{A word on the dialogue with the previous frameworks of participating subjects}

The population group, which we worked with, is characterized by sharing previous frameworks on self-care that are highly influenced by predominant national-catholic values of their childhood and youth. Values such as "divine providence"; the development of a "passive role" especially identified with the woman; the "lack of public expression" and the exercise of "humility"; the practice of chastise; the "lack of recognitionvalor of the other"; the notion of the aging process as a "decaying phase"; among others, are present in the statements and practices of this group, thus restricting and depriving their exercise of freedom and autonomy. They gave up the liberty to make decisions on their own lives and self-care practices, grounded on equality and autonomy, and decided to leave such decisions on the hands of other people (professionals and God). The following statements illustrate these ideas.

P4: well, all of us die when God wants us to

P19: no, we've been shut up for so long, our generation has shut the voice of women, very much (S5-Gp).

P20: you were never told whether or not you were doing things right, you were always reproached when you did things wrong (S6-Iz).

These previous frameworks shared by the participants needed to be unfolded and taken into account by the self-care educational actions. They might disagree with the milestones shared by the nurses, but they have to be exposed if we really want to conjointly build and design goals and actions that establish a dialogue between these frameworks and the knowledge they generate.

The previous frameworks of the groups not only affect their way of understanding self-care and health, but also the vision they have about sanitary professionals and the way they should relate to them. The study showed that they keep looking at sanitary professionals as experts, and transfer to them their trust and decision-making power on the self-care practice. P2: Yes. Now, after pondering about some points, you [educational nurses] can decide, like, let's list three [issues] in the conversation... We think that you will do the best for us, of course (S0-Iz).
In the educational interaction, we observed how the participants give the power of the specialized knowledge and establish unidirectional correlations with it, thus hindering the sharing process and the egalitarian dialogue. Such fact is also influenced by the biomedical domain power, which caused the population to limit their self-care capacity, establish paternalistic relationships with the nurses, create dependence bonds, relegating the role of "patients" to a passive and mere recipient role. ${ }^{16}$ In other words, the previous frameworks of this group, resulting from the usurpation of their self-care power by healthcare professionals, affect and mediate this type of correlation (unidirectional), their (passive) role, and the expectations they have concerning the sessions (to be filled with knowledge). The following statement clearly shows the existing shock between the expectations of the group and the pedagogical proposals of the nurses: P4: well, I heard people saying many times that you would intervene more, you know... They believed that you would instruct us, but in the end you were asking us about our opinions. Then, they said that they would not go there to listen to other people [participants], they thought this would not be interesting at all (N-P4).

Hence, as empowering agents, we have to facilitate the awareness of these groups about such previous milestones (perspectives) and their restrictive elements by making use of reflexive exercises, so that we can advance toward more autonomous milestones, less dependent upon professionals. We defend that professionals become facilitators of critical reflection exercises on self-care practices carried out by individuals and groups, where they can conjointly participate in the liberation of restrictive aspects, in order to transform and modify their perspectives. Therefore, our challenge is to make bridges that can articulate different perspectives and breakthrough the previously described restrictive frameworks.

\section{A word on the nurses' liberation from restrictive previous technical and positivist perspectives}

Healthcare education is mediated by power relations that generate different interests and cultural perspectives. As such, the perspective of nurses directly influences practices generated in educational action. ${ }^{17-18}$ In our case, the paradoxes and contradictions of the educational action, as well as the continuum of technical-practicalemancipatory interests present in such action, are 
clearly observed. In other words, despite the interest in constructing an educational action based on a practical-emancipatory interest, the previous technical frameworks of nurses negatively affect such purpose, thus creating the above-mentioned contradictions and paradoxes. Such fact can be observed in the following statement uttered by one of the nurses on an exercise called "word dynamization", when a tension among the foment of a participatory process and an egalitarian dialogue (empowerment) and the need for controlling the participation of the players (quit the empowerment) is created N1: this thing of empowering the participation scares me, above all when it is related to people who are not used to it, people who know they can intervene, but who are forced to shut up... That's why many professors do not risk participating in these processes. It's quite an organized process when you say "this", "this" and "this", and then, at the end, you can ask, "any question?", but in a very slow pace (Rs-A-3).

This finding is also present in other studies that showed the complexity of such change, where knowledgeable educators committed with the egalitarian dialogue proposal ended up performing pedagogical practices centered on informative and persuasive-motivational models that paradoxically corresponded to the model they were trying to alter. ${ }^{19-20}$

Distinct elements influence the perspective on which the care action performed by the nursing professional is carried out. A key element is the different type of socialization process the nurse experiences in her professional group. ${ }^{21} \mathrm{In}$ this sense, the initial and permanent education of professionals emerges as a crucial step. Health education is composed of highly complex and uncertain situations and processes in which conflicts of values are observed. This is why professional training programs toward a more critical analysis of such complexities and uncertainties have to be intensified, in such a way that professionals do not merely respond to technical interests, where their personal knowledge and practical experiences are eliminated in favor of the application of a series of scientific norms and regulations, yet totally detached from the practical reality. ${ }^{22}$

As a result, professional improvement and qualification processes should be encouraged, yet emerging from the nurses' own experience, where knowledge is not segregated from its application context. Therefore, the professional experience and its practical components should be considered as focal axles through which the learning process takes place. This present study shows how a reflexive exercise on an educational action facilitates the identification of previous frameworks, and how an analytical exercise of meaning schemes is able to move us toward overriding such restrictive elements. N2: ... there have been many things in your speech you do not realize what you're thinking. You say something, and then you have to move backwards and think more deeply and effectively about it. You realize that you have internalized a series of things that come out so spontaneously (RsA-6).

Another element that delimitates our professional socialization stands out as another institutional framework: the predominant rationality in such power framework. Institutions are characterized as hegemonic structures, as ideas, values and beliefs of dominant groups in the society are usually carried out in the way they are designed and as a result of how much they saturate the subjectivity of the members of that society. ${ }^{23} \mathrm{In}$ this study, the positivist, technical and predominantly biomedical rationality present in the system prevents the educational self-care practice from moving toward more liberating, less authoritarian and dependent guidelines. If the academic and professional background of the new nurses used to play a determinant role in the organization of their subjectivity, the healthcare institutions they work at are currently responsible for the perpetuation of such status. In our case, the institution not only supported the perpetuation and legitimization of power relations and dependence, but also has historically delegitimized and downgraded educational actions. Consequently, as observed by N1 below, professionals have historically lacked time and places to implement such actions. N1: ... I believe that the management and the organization need to address education as an important action. As such, it can't be done in your free time. It should mean the presence of educational nurses who enjoy heal thcare education. They need to receive strategies and training in order to perform the actions effectively in their labor period... (RsA-6).

Hence, we observe that healthcare programs are often defined without taking target subjects into account in the educational intervention plan. Professionals have insufficient training programs and therefore organize poor models based on theoretical milestones that respond to a one and only technical-practical interest that does not address the key elements highlighted above. 


\section{A word on the power of the discourses}

In this study, the statements of the nurses reflect their epistemological standpoints on health and self-care practice, which transcend selected contents. In other words, the discourses convey implicit values, ideas and beliefs about health care, acquiring special relevance in the educational action, as they can either contribute to the perpetuation of paternalistic relations and foment limited, dependent and fragmented self-care notions, or move toward more humanist and social-critical perspectives.

Whenever they are grounded on technical interests, the discourses are characterized by a fragmented notion of the human being, and health care is merely guided toward responding to lacks of capacity or deficits. The supremacy of the theory is deemed to orient the practice, where the subject (professional, owner of knowledge) and the object (patient, recipient) are generally set apart, thus perpetuating paternalistic, unequal relationships disconnected from the contexts and values of the action. That is, professionals clearly express their restrictive, narrow, absolutist, reactive and paternalistic backgrounds, where knowledge stands out as an exclusive ownership of the professional. N1: well, if one has high cholesterol, he'll have to listen and do what the doctor and the nurse says. (S2-Iz).

The nurses also quoted other components referred to liberating beliefs built on practical interests, such as a holistic idea of the human being, the need for sharing a systemic view about life, and the ever-changing status of life. N1: people are not limited to their physical bodies. We are physical, mental and spiritual beings. Depending on the perception one has about himself, he'll take 15 pills a day, but if the person feels fine, everything changes (S1-Iz).

By whole and unique beings we mean that the subjectivity and singularity of the human being will always be recognized. As such, professionals should understand that the distinct emotions, experiences, values and meanings experienced by different people should be respected. That is, when self-care can be differently put into practice in similar healthcare situations.

Another element that characterizes an educational construction based on such interest is the one related to the non-medicalization of self-care. The following statement encourages the search for natural strategies originated in the cultural knowledge of people in the studied population group. R: and also try something natural, such as tilia, melissa, valerian infusions, ... they tend to be soothing and relaxing ( $\mathrm{S} 4-\mathrm{Gp})$. Moreover, at highlighting the responsibility people have to self-care, these statements encourage the abandonment of paternalism and power positions. Here, the professional no longer fills people with knowledge or establishes unilateral action agendas, but encourages people to move forward and become protagonists of their own care.

The social-critical perspective indicates that the statements show a progress toward a more critical reflection on the predominant challenges of our time, as well as the different care areas, the aging process, feeding behaviors, communication with other people, and adopted societal roles. N2: well, look at what publicity does. The lady [in the video] said it very well. She said that they create needs in us, they make a new product and then everybody goes like, 'mmm, let's have it' (S4-Iz).

Statements like the one below recognize traditional self-care practices as valid, legitimate mechanisms, and thus hand the care power back to the population. N2: your learning is based on your experiences...it's a special wisdom. Look for yourself how many home medicines and procedures you already know, a bit of everything. I have learned very much with you (S1-Gp).

Another component of the discourses is the relativization and contextualization of each uttered belief applied in distinct situations and to different individuals, without any need for emphasizing general technical recommendations. R:people should decide their own pace. There are people like this, I can stroll for one hour but I have to stop three times. Well, each one should adapt to their capacities (S3-Gp).

\section{CONCLUSIONS}

This present research showed how the perspectives of the participants in educational actions (mature adults) and the nurses, in distinct occasions, differ from each other in the way they understand the educational process and self-care, thus generating power relations, conflicts and paradoxes in the educational actions. Such condition implies the assimilation of a plural, relativistic perspective of reality, in such a way that it generates a dialogue among different knowledge and ways of comprehending the world, thus leveling power relations and dependence statuses.

This study revealed the contradictions and paradoxes observed in the practical action, as well as the difficulties toward producing pedagogical 
changes in health education, as it is generally sustained by traditional models. This requires professionals to search for a transformation of their practice toward a liberation from restrictive previous frameworks. This quite complex issue is not merely solved from an informative training. A reflexive practice has been emerging as a key to generate and advance the professional knowledge toward the construction of new frameworks.

The restrictive elements observed within the institutional context lead us to come up with actions that facilitate more empowering systems to the population. As previously indicated, the first step refers to the strengthening and facilitation of reflexive exercises on the professional action, in such a way that nurses help identifying previous frameworks and become aware of restrictive elements toward the educational action. Based on these changes, professionals can rebuild their praxis, create new, transcending critical masses toward other possible care approaches. Another action could take into account the studies carried out on the practical action. This work should address issues such as what has been done, and how it has been done, in the health education field toward the generation of solutions that really qualify individuals and groups in health-based issues, as proposed by the present study.

Finally, we can affirm that this research was able to provide clear evidences on how more humanistic beliefs and discourses can lead us away from paternalism and the fragmentation related to the self-care practice. Additionally, more critic and relativistic discourses draw us closer to more egalitarian actions and to the empowerment of the population, thus facilitating the mobilization of these groups toward a more liberating epistemological position, and consolidating the pillars of a dialogic healthcare learning.

\section{REFERENCES}

1. Habermas J. Conocimiento e interés. Madrid (ES): Taurus; 1982.

2. Carr W, Kemmis S. Teoría crítica de la enseñanza. Barcelona (ES): Martínez Roca; 1998.

3. Medina JL, Sandín M.P. La complejidad del cuidado y el cuidado de la complejidad: un tránsito pedagógico de los reduccionismos fragmentantes a las lógicas no lineales de la complejidad. Texto Contexto Enferm. 2006 Abr-Jun; 15(2):312-9.

4. Medina JL. Pedagogía del cuidado: saberes y prácticas en la formación universitaria española en enfermería. Barcelona (ES): Laertes; 1999.
5. Márquez S, Meneu R. La medicalización de la vida y sus protagonistas. Eikasia Rev Filosofía. 2007; II (8):65-86.

6. Peñaranda F, Torres JN, Bastida M, Escobar G, Arango A, Pérez FN. La praxis como fundamento de una educación para la salud alternativa: estudio de investigación-acción en el Programa de Crecimiento y Desarrollo en Medellín, Colombia. Interface (Botucatu). 2011; 15(39):997-1008.

7. Bastida M, Pérez FN, Torres JL, Escobar G, Arango A, Peñaranda F. El diálogo de saberes como posición humana frente al otro: referente ontológico y pedagógico en la educación para la salud. Invest Educ Enferm. 2009; 26(1):104-11.

8. Medina JL. Imágenes del otro. A propósito del sujeto destinatario de las prácticas de educación para la Salud [firma invitada]. RIdEC. 2012 [acesso 2014 Feb 24]; 5(2). Disponível em: http:/ / enfermeriacomunitaria.org/web/index.php/ridec/77-ridec-2012-volumen-5-numero-2/445-firma-invitada-imagenes-del-otro-a-proposito-del-sujeto-destinatario-de-las-practicas-de-educacion-para-la-salud

9. Medina JL, Sandín MP. Epistemología y enfermería: paradigmas de la investigación en enfermería. Enferm Clín.1995; 5(1):3245.

10. Guba E, Lincoln Y. Cap 6: Competing paradigms in qualitative research. En: Denzin N, Lincoln Y. Handbook of qualitative research. London (UK): Sage; 2000.

11. Carr W, Kemmis S. Teoría crítica de la enseñanza. Barcelona (ES): Martínez Roca; 1998.

12. Schensul SL, Schensul JJ, LeCompte MD. Essential ethnographic methods: Observations, interviews, and questionnaires. Book 2: Ethnographer's toolkit. Walnut Creek (CA): AltaMira Press; 1999.

13. Valles M.S. Técnicas cualitativas de investigación social. Reflexión metodológica y práctica profesional. Madrid (ES): Síntesis; 1997.

14. Glaser B, Strauss A. The discovery of grounded theory: strategies for qualitative research. New York (US): Aldine Publishing Company; 1999.

15. Criado E. Del sentido como producción: elementos para un análisis sociológico del discurso. En: Latiesa M. El pluralismo metodológico en la investigación social. Granada (ES): Universidad de Granada; 1991. p.87-212.

16. Comelles JM. La utopía de la atención integral en salud. Autoatención, práctica médica y asistencia primaria. Revisiones en Salud Pública. 1993; 3: 169-192.

17. Mejía MR. La educación popular: hacia una pedagogía política del poder. Aportes. 1996; (46):1939.

18. Bruner J. Actos de significado; más allá de la revolución cognitiva. Madrid (ES): Alianza Editorial; 2009. 
19. Peñaranda F, Bastidas M, Escobar G, Torres JN, Arango A. Análisis integral de las prácticas pedagógicas de un programa educativo en Colombia. Salud Pública Méx. 2006; 48(3):229-35.

20. Torres JN, Peñaranda $F$, Bastidas $M$, Escobar G, Pérez FN, Arango A, Rivas E. El educador como investigador de su práctica pedagógica; la importancia de la reflexión en la educación para la salud. Rev Salud Publica. 2010; 28(2):161-268.
21. Benner P, Tanner C, Chesla C. Expertise in nursing practice. Caring, clinical judgment and ethics. New York (US): Springer, publishing Company; 2009.

22. Medina JL, Do Prado ML. El curriculum de enfermería como prototipo de tejné: racionalidad instrumental y tecnológica. Texto Contexto Enferm. 2009 Out-Dez; 18(4):617-26.

23. Apple M. Ideología y currículo. Madrid (ES): AKAL/Universitaria; 2009. 